M. Andral and to the Cyclopædia of Practioal Medicine, being a complete series of coloured lithographic drawings from originals by the author". $\mathrm{He}$ died on May 12, 1841, at the early age of forty.

\section{Spectrochemical Literature}

THE second volume of Spectrochemical Abstracts, covering the years 1938-39 and edited by E. H. S. van Someren, has just been issued by Messrs. A. Hilger, 98 St. Pancras Way, N.W.1. More than 150 papers and books are listed under authors' names, and the classification of substances analysed and elements determined is very thorough. The pamphlet is a valuable summary of material scattered in many journals.

Books and papers of metallurgical interest are similarly covered by the Bibliography of Spectrochemical Analysis compiled by D. M. Smith and published by the British Non-Ferrous Metals Research Association, Euston Street, N.W.1. The second edition, costing three shillings, has been brought up to date, to August 1940, and now includes more than five hundred entries. A new section on Application of the Microphotometer lists twenty-one researches. Short explanatory notes are given with most of the references and an author index is provided.

\section{Earthquake in Manchuria}

AN earthquake of considerable intensity is reported to have taken place early on May 6 in northern Manchuria. Insufficient reports have so far been received to fix the epicentre with any precision but it must have been fairly close to Suihwa, forty miles north-east of Harbin, where thirty-three were killed and several injured. It is also reported that scores were killed and injured in other nearby cities. It will be recalled that one of the larger earthquakes of 1940 took place in Manchuria on July 10.

\section{Institution of Electrical Engineers: Awards}

THE Council of the Institution of Electrical Engineers has made the following award of premiums for papers read during the session 1940-41, or accepted for publication : Institution Premium : Mr. C. F. Booth; Ayrton Premium : Mr. W. A. Cook; Fahie Premium: Messrs. A. Fairweather and J. Ingham; John Hopkinson Premium: Mr. G. H. Rawcliffe; Kelvin Premium : Messrs. C. E. R. Bruce and R. H. Golde; Extra Premiums : Mr. C. G. Garton, Messrs. L. Gosland and W. F. M. Dunne, Prof. Willis Jackson and Mr. A. E. Chester, Dr. R. Jessel, Messrs. W. J. Mason and S. A. G. Emms, Mr. G. H. Metson, Mr. A. Langley Morris; Wireless Section Premiums : Messrs. N. M. Rust, O. E. Keall, J. F. Ramsay and Dr. K. R. Sturley (Ambrose Fleming Premium), Messrs. C. A. Mason and J. Moir, Dr. R. H. Barfield; Meter and Instrument Section Premiums : Dr. A. E. W. Austen and Dr. S. Whitehead, Mr. A. J. King, Dr. R. W. Guelke, Mr. C. R. Maguire and Dr. R. A. Scott; Transmission Section Premiums : Mr. F. R. Perry (Sebastian de Ferranti Premium), Dr. C. Dannatt and R. A. Polson.

\section{Announcements}

The Sir John Kennedy Medal of the Engineering Institute of Canada has been presented to LieutenantGeneral A. G. L. McNaughton, commander of the Canadian Corps in Great Britain and lately president of the National Research Council of Canada. General McNaughton described the present position of research in Canada before a meeting of the Royal Society of Arts on May 13; we hope to print a substantial part of this lecture in an early issue.

Prof. L. G. M. BAAs BECKING, professor of botany in the University of Leyden and director of the well. known Leyden Botanical Gardens (NaturR, 142, 1013 ; 1938), is now in custody in a prison at Scheveningen, Holland.

Dr. Thomas Midgley, Jun., of Kinetic Chemicals, Inc., has been awarded the Priestley Medal, the highest award of the American Chemical Society, for his discovery of the anti-knock properties of tetraethyl lead, as well as other outstanding achievements in chemical science. Dr. Midgley has already been awarded the Nichols, Longstreth and Perkin Medals.

The thirty-first annual May Lecture of the Institute of Metals will be delivered in the New. Clarendon Laboratory, Oxford, by Dr. F. Simon, reader in thermodynamics in the University of Oxford, on May 28. Dr. Simon will speak on "The Significance of Low Temperature Research". Admission is by ticket, obtainable free of charge, from the Secretary, Institute of Metals, 4 Grosvenor Gardens, London, S.W.1, or the Secretary, Clarendon Laboratory, University Museum, Oxford.

THE following appointments in the Colonial Service have recently been announced: D. T. Lloyd, surveyor, Sierra Leone; E. B. Lambert (assistant superintendent of Crown lands), superintendent of Crown lands and surveys, Hong Kong; L. Lord (formerly divisional agricultural officer, Ceylon), secretary to Colonial Advisory Council of Agriculture and Animal Health and assistant to Agricultural Adviser, Colonial Office.

THE following appointments in the University of Sheffield have recently been made : Dr. S. A. Peyton, University librarian; Mr. F. J. S. Esher, assistant lecturer in mental diseases; Mr. M. Laird, junior demonstrator in anatomy ; Mrs. Mildred John, parttime demonstrator in anatomy.

The Council has received from the executor of the late Mrs. E. G. Willis a cheque for $£ 1,000$ in payment of a legacy left to the University for the foundation of a scholarship in engineering or metallurgy in memory of her late husband, Mr. T. W. Willis.

The collaborators of the late Prof. R. V. Wheeler have presented to the University a complete set of his published researches, together with a glass cabinet to contain the volumes.

The Council has received the resignation of Dr. F. E. E. Schneider of his post of assistant lecturer in mental diseases, and Mr. T. C. Joyce of his post of lecturer in electrical engineering. 